\title{
Real Time Monitoring of Water Quality in Supply Pipelines and Industrial Facilities
}

Calvi, F.A. ${ }^{1,}{ }^{*}$, Ramos, G.P. ${ }^{2}$, Tundisi, J.G. ${ }^{3}$, Ghiglieno, F.G. ${ }^{1}$

'Federal University of São Carlos, Department of Physics, São Carlos, SP - Brazil

${ }^{2}$ Paulista University, Department of Mechanical Engineering, Araraquara, SP - Brazil

${ }^{3}$ International Institute of Ecology, São Carlos, SP - Brazil

Corresponding author: felipe.calvi@df.ufscar.br

\section{Abstract}

The main goal of this project is to findalow costlot solution for real-time monitoring of water quality. With the support of a sensors network, we should be able to collect inorganic parameters in water for both domestic and industrial applications. For the first time, this tool can allow to monitoring and control the water chemical and physical data along the mains water supply and distribution. The projectrelies on support of development companies such as FAPESP and with collaboration of the International Institute of Ecology in partnership with Matsu-Aquatech and the Innovation Agency of UFSCar.

Keywords: internet of things, sensors network, real-time monitoring, water quality. 


\section{Introduction}

All living things depend of water to survive and we, human beings, are not an exception. However, water goes beyond our biological needs. We require water in our everyday activities, from washing our dishes, to the cleaning of industrial equipment or dissolution of chemical drugs. All those processes depend on the water quality.

In this context, the applicable local regulations aim to define standards for the water quality combining several physical and chemical parameters.

But nevertheless, there is evidence that Humanity's inadequate actions on the environment impacts the dynamic equilibrium in the Nature. It is an example the degradation of river waters, which, by the time, have considerably deteriorated due to the precariousness of basic sanitation and the increasing of industrial pollution. Therefore, monitoring of water quality is now a mandatory step for the preservation, the analysis and where possible the possible recovery on the basis of safety standards from the Health Ministry (MINISTÉRIO DA SAÚDE, 2011).

\section{Justification}

The amount of chlorine, well-known bactericide, in the drinking water is one of the parameter available on the water bills in São Carlos. Since December 2015 we have monitored this value and we observed in the region next to the Federal University of São Carlos an average value of $1.2 \mathrm{mg} / \mathrm{L}$, six times $0.2 \mathrm{mg} / \mathrm{L}$, the minimum amount fixed by SABESP (Basic Sanitation Company of the State of Sao Paulo) (SABESP, 2017).

In the scientific literature, it is documented a correlation between an excess of chlorine and the breast cancer (SCIENTIFC AMERICAN, 2017). There is also evidence of that this chemical element be detrimental to kidneys and liver (DEN BESTEN, CATHALINE et al., 1991). In addition, the chemical reactions of chlorine with the environment can impact in producing carcinogenic toxins exposed in nature (DRECHSLER, P.A., WILDMAN, E.E. and PANKEY, W., 1990).

Made aware of the consequences for our health and for the environment, we have started to develop a compact, reconfigurable, hot-pluggable and low-cost stations for monitoring in real time the water chemical and physical parameters along the mains water supply in the city (FAPESP - PIPE: 2017/15930-4 and UFSCar ProEx $23112.003836 / 2015-99)$. For this purpose, we work on integrating sensors in an equipment able to measure, record and send data in real time for modeling, monitoring and, if necessary, taking action. We are looking for a standardization of water quality verification in our city. The project is interdisciplinary and takes advantages from the collaboration with the International Institute of Ecology (IIE - São Carlos) and from the support of the company Matsu-Aquatech. 


\section{Methods and Materials}

The prototype benefits from sensors both available on the market and self-fabricated.

A microcontroller manages the sensors, extracts and records the data. Firstly, the equipment will be tested and calibrated in the Óptica, LAser Fotônica laboratory - ÓLAF/DF-UFSCar (see Figure 1) with 'ad-hoc' samples prepared by the International Institute of Ecology. In this way, we expect to reach a high sensitivity, making our architectural solution competitive with others, more expensive, available on the market.
In a second stage of the project, the stations will be installed in different place along the water supply network. Adopting different solutions depending on the available network facilities, the equipment will transmit processed information (e.g. $\mathrm{pH}$, flux, temperature, etc.) to the data processing workstation.

The collected data are going to be analyzed and modelled by expert in the area. This monitoring facilities will be a precious tool for all the enterprises working with water and water distribution.

The authors in collaboration with the Innovation Agency (UFSCar) work on the documentation to submit the patent to the INPI agency.

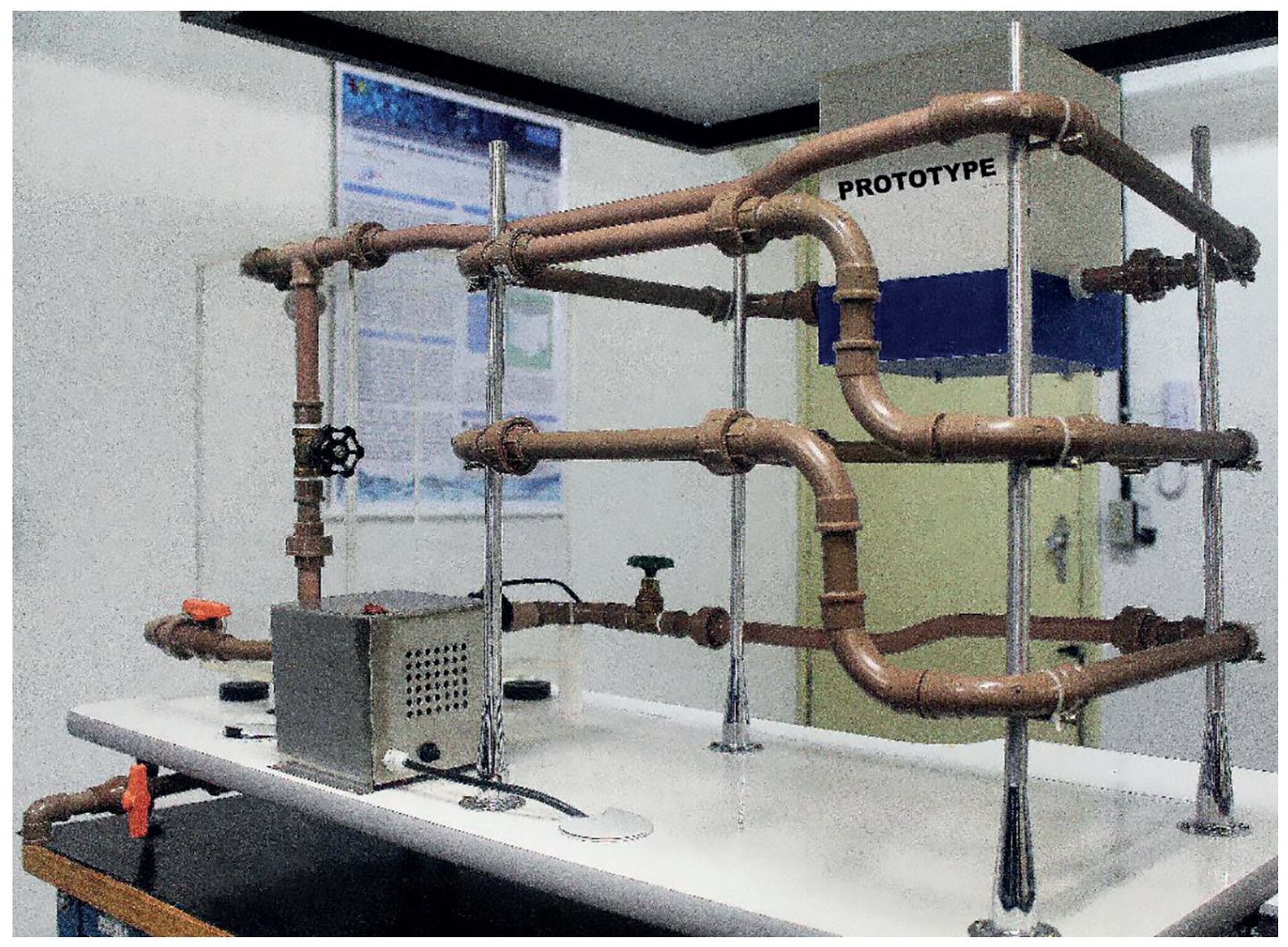

Figure 1 - Testing apparatus for the prototype (courtesy of Laboratório de Óptica, Laser e Fotônica - ÓLAF/DF-UFSCar). 


\section{References}

MINISTÉRIO DA SAÚDE. Portaria no 2914, de 12 de dezembro 2011. Available in: http://bvsms.saude. gov.br/bvs/saudelegis.

SABESP, 2017. Qualidade da água. Available in: http://site.sabesp.com.br/site/interna/Default. aspx?secaold=40. Access: Dec. 2017.

SCIENTIFC AMERICAN, 2017. Tapped Out? Are Chlorine's Beneficial Effects in Drinking Water Offset by Its Links to Cancer? Available in: https://www. scientificamerican.com/article/earth-talks-tappedout. Access: Dec. 2017
DEN BESTEN, CATHALINE et al., 1991. The liver, kidney, and thyroid toxicity of chlorinated benzenes. Toxicology and applied pharmacology, vol. 111, no. 1, pp. 69-81.

DRECHSLER, P.A., WILDMAN, E.E. and PANKEY, W., 1990. Evaluation of a chlorous acid-chlorine dioxide teat dip under experimental and natural exposure conditions. Journal of Diary Science. 